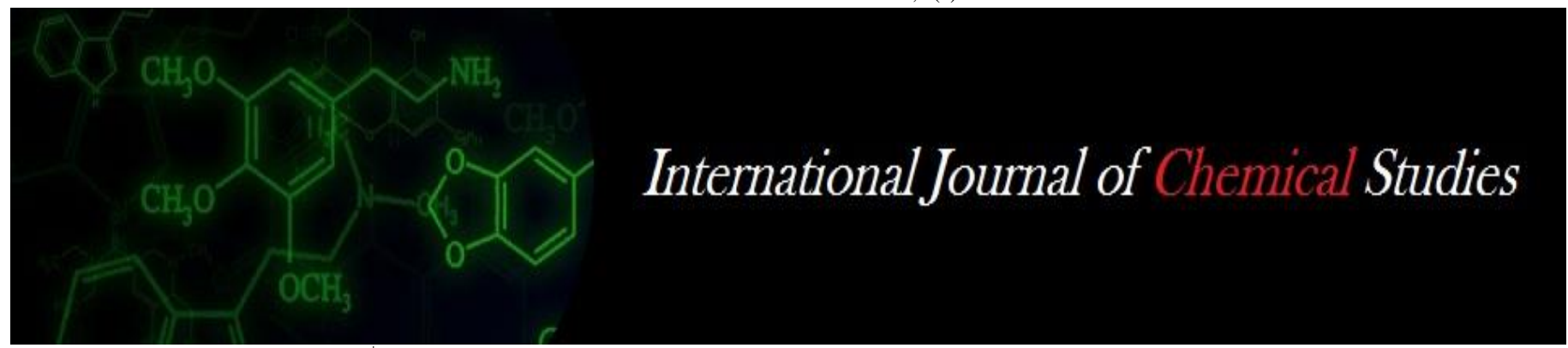

P-ISSN: 2349-8528

E-ISSN: 2321-4902

www.chemijournal.com

IJCS 2021; 9(1): 3634-3636

(C) 2021 IJCS

Received: 19-11-2020

Accepted: 02-01-2021

Avnish Kumar Yadav

Ph.D Vegetable Science, N.D.

University of Agriculture \&

Technology, Kumarganj,

Faizabad, Uttar Pradesh, India

GC Yadav

Assistant Professor, Department

of Vegetable Science, N.D.

University of Agriculture \&

Technology, Kumarganj,

Faizabad, Uttar Pradesh, India

RC Jaiswal

Ex.- Professor \& Head,

Department of Vegetable

Science, N.D. University of

Agriculture \& Technology,

Kumarganj, Faizabad, Uttar

Pradesh, India
Corresponding Author: Avnish Kumar Yadav Ph.D Vegetable Science, N.D. University of Agriculture \&

Technology, Kumarganj,

Faizabad, Uttar Pradesh, India

\section{Studies on genetic variability for yield and quality attributes in bottle gourd [Lagenaria siceraria (Mol.) Standl.]}

\author{
Avnish Kumar Yadav, GC Yadav and RC Jaiswal
}

DOI: https://doi.org/10.22271/chemi.2021.v9.i1ay.11796

\begin{abstract}
The estimates of phenotypic and genotypic coefficients of variation, heritability and genetic advance among yield, quality and its components characters in 36 parents and $\mathrm{F}_{1} \mathrm{~S}$ of bottle gourd were worked out from the experiment conduct over two years at Department of Vegetable Science, N.D. University of Agriculture \& Technology, Kumarganj, Faizabad. High degree of variations was observed for all the characters studied. Number of primary branches per plant, T.S.S., ascorbic acid, non-reducing sugar and dry matter showed high estimates of phenotypic and genotypic coefficients of variations, heritability and genetic advance in both the years. These results indicates preponderance of additive genetic components which will be help full for further developing bottle gourd genotypes possessing high yield with better quality.
\end{abstract}

Keywords: genetic variability, Yield, bottle gourd

\section{Introduction}

Bottle gourd [Lagenaria siceraria (Mol.) Standl.] is an important Vegetable crop in India cultivated throughout the country belongs to family cucurbitaceae, having chromosome number $2 n=22$. It is grown in most of the states like U.P., Bihar, West Bengal, Assam, Punjab and Gujarat. The green edible fruits are consumed for vegetable purpose. Bottle gourd is said to very useful in curing diabetes. The leaf juice is used for the treatment of blindness. The seeds are used in dropsy. Information on the magnitude of variation in the available genetic material and the part played by the environment on the available genetic material and the part played by the environment on the expression of plant characters are the prime importance for the appraisal of the rate and magnitude of possible improvement. Further, estimates of heritability and genetic advance would give the best picture of the extent of improvement excepted from selection and reliability at selection based on phenotype. The present investigation is an attempt in that direction.

\section{Materials and Methods}

In the present investigation eight diverse genotypes of bottle gourd viz., Pusa Naveen $\left(\mathrm{P}_{1}\right)$, NGBG-504 ( $\left.\mathrm{P}_{2}\right)$, NDBG-509 ( $\left.\mathrm{P}_{3}\right)$, NDBG-525 ( $\left.\mathrm{P}_{4}\right)$, NDBG-601 ( $\left.\mathrm{P}_{5}\right)$, NDBG-603 ( $\left.\mathrm{P}_{6}\right)$, NDBG$624\left(\mathrm{P}_{7}\right)$ and NDBG-625 $\left(\mathrm{P}_{8}\right)$ were crossed with all possible combinations $\left(28 \mathrm{~F}_{1} \mathrm{~s}\right)$ excluding reciprocals. The $\mathrm{F}_{1}$ hybrids and parents were evaluated during summer (Zaid) crop Seasons of $2008\left(\mathrm{Y}_{1}\right)$ and $2009\left(\mathrm{Y}_{2}\right)$ in randomized block design (RBD) with three replications at Department of Vegetable Science, N.D. University of Agriculture \& Technology, Kumarganj, Faizabad. The experiment was conducted in single row of 3 meters length with row to row spacing of 3 meters and plant to plant spacing of $50 \mathrm{~cm}$ apart six plants were maintained in each plot. The recommended agronomic practices were followed to raise good crops. Observations were recorded from all the six plants of each treatment and replications for days to first staminate flower opening, days to first pistillate flower opening, node number to first staminate flower, node number to first pistillate flower, days to first fruit harvest, vine length $(\mathrm{m})$, number of primary branches per plant, fruit length $(\mathrm{cm})$, fruit circumference $(\mathrm{cm})$, fruit per plant, average fruit weight $(\mathrm{Kg})$, fruit yield per plant (Kg.), T.S.S. (\%), ascorbic acid $(\mathrm{mg} / 100 \mathrm{~g})$, reducing sugars $(\%)$, non-reducing sugar $(\%)$ and dry matter $(\%)$. Heritability and 
genetic advance were studied by the diallel method of numerical approach given by Mather and Jinks (1971) ${ }^{[2]}$ and Johnson et al. (1955) ${ }^{[1]}$, respectively.

\section{Results and discussion}

The analysis of variance showed significant differences due to genotypes for all the seventeen traits in both the years under studies. This indicates sufficient genetic variability to be exploited in a breeding programme and was reflected in the broad range observed for each characters presented in Table 1. The extent of variability in parents and their $F_{1}$ hybrids of bottle gourd were measured in terms of grand mean range, genotypic and phenotypic coefficient of variation over two years presented in Table-2. The parents and $F_{1}$ hybrids presented considerable diversity in fruit yield and quality attributes when grown in two years and thus showed great potential for selection of promising types.

The phenotypic and genotypic coefficients of variation (PCV and GCV), heritability in broad sense and genetic advance as per cent of mean were worked out to various morphological and quality traits (Table 2). In general, the estimates of PCV were higher than GCV for all the traits. However, low magnitude of differences was observed between GCV and PCV indicating less environmental influence. Number of primary branches per plant, fruit yield per plant, number of fruits per plant, node number to first staminate flower, vine length, non-reducing sugar, reducing sugar, TSS, dry matter and ascorbic acid exhibited the moderate to high PCV and GCV estimates in both the years $\left(\mathrm{Y}_{1}\right.$ and $\left.\mathrm{Y}_{2}\right)$. High values of GCV are an indication of high genetic variability among the parents and $F_{1}$ hybrids which showed the scope of improvement of these characters through selection. The findings are in close agreement with the results of Narayana $e t$ al. (1996) ${ }^{[3]}$ in bottle gourd and Varalakshmi et al. (1995) ${ }^{[7]}$ in ridge gourd.

The efficacy of selection not only depends on the magnitude of variability present in a trait but also on the extent of heritability of the desirable characters. Estimates of high heritability for ascorbic acid, dry matter, T.S.S. number of primary branches per plant and non-reducing sugar in both year $\left(Y_{1}\right.$ and $\left.Y_{2}\right)$. Whereas, for reducing sugar and vine length in year $\left(\mathrm{Y}_{1}\right)$ and for fruit yield per plant, fruit length, days to first staminate and pistillate flower opening and days to first fruit harvest in year $\left(\mathrm{Y}_{2}\right)$. High heritability can be attributed due to the greater role of additive and additive $\mathrm{x}$ additive gene action, which can be exploited by following the selection in these traits. These results confirm the findings of Sahni et al. (1987) [5], Varalakshmi et al. (1995) [7] and Panse and Sukhatme (1957) ${ }^{[4]}$. Estimates of heritability computed along with genetic advance are more useful than heritability alone. High heritability coupled with high genetic advance were noted for number of primary branches per plant, ascorbic acid and TSS in both the years $\left(\mathrm{Y}_{1}\right.$ and $\left.\mathrm{Y}_{2}\right)$. This indicates the less influence of environment on these traits. So the improvement could be made through selection. These findings are in accordance with those of Singh et al. (2005) ${ }^{[6]}$ and Wani et al. $(2008)^{[8]}$.

It could be concluded that sufficient genetic variability present for all the characters studied, Hence, the best genotypes can be used in further breeding programs for improving the specified traits. High heritability along with high genetic advance might be due to additive gene action. High estimates of phenotypic and genotypic coefficient of variation, heritability and genetic advance for characters like number of primary branches per plant, ascorbic acid and T.S.S. suggested that selection based on phenotypic values of these characters will be more effective for improvement.

Table 1: ANOVA (mean squares) for a set of $8 \times 8$ diallel cross in bottle gourd over two years $\left(\mathrm{Y}_{1}, \mathrm{Y}_{2}\right)$

\begin{tabular}{|c|c|c|c|c|c|c|c|c|c|c|}
\hline $\begin{array}{l}\text { Source of } \\
\text { Variation }\end{array}$ & Years & d.f. & $\begin{array}{c}\text { Days to first } \\
\text { staminate } \\
\text { flower opening }\end{array}$ & $\begin{array}{c}\text { Days to first } \\
\text { pistillate flower } \\
\text { opening }\end{array}$ & $\begin{array}{c}\text { Node number to } \\
\text { first staminate } \\
\text { flower }\end{array}$ & $\begin{array}{c}\text { Node number } \\
\text { to first } \\
\text { pistillate flower }\end{array}$ & $\begin{array}{c}\text { Days to } \\
\text { first fruit } \\
\text { harvest }\end{array}$ & $\begin{array}{c}\text { Vine } \\
\text { length } \\
(\mathbf{m})\end{array}$ & $\begin{array}{l}\text { Number of primary } \\
\text { branches per plant }\end{array}$ & $\begin{array}{l}\text { Fruit } \\
\text { length } \\
\text { (cm) }\end{array}$ \\
\hline \multirow{2}{*}{ Replications } & $Y_{1}$ & 2 & 3.78 & $14.41 * *$ & 0.74 & 1.83 & $11.68 *$ & 0.027 & 0.29 & 1.80 \\
\hline & $\mathrm{Y}_{2}$ & 2 & $5.68 *$ & $7.92 * *$ & 1.70 & 0.42 & $12.63 * *$ & 0.77 & 4.55 & 2.12 \\
\hline \multirow{2}{*}{ Genotypes } & $Y_{1}$ & 35 & $14.38 * *$ & $16.56 * *$ & $3.83 * *$ & $2.88 * *$ & $15.51 * *$ & $1.84 * *$ & $23.81 * *$ & $25.93 * *$ \\
\hline & $\mathrm{Y}_{2}$ & 35 & $16.99 * *$ & $17.34 * *$ & $4.20 * *$ & $5.35 * *$ & $23.70 * *$ & $1.24 * *$ & $24.29 * *$ & $31.82 * *$ \\
\hline \multirow{2}{*}{ Error } & $\mathrm{Y}_{1}$ & 70 & 1.87 & 1.84 & 0.69 & 0.77 & 3.08 & 0.12 & 1.76 & 2.63 \\
\hline & $\mathrm{Y}_{2}$ & 70 & 1.30 & 1.63 & 0.65 & 0.95 & 2.24 & 0.29 & 1.92 & 1.82 \\
\hline
\end{tabular}

Table 1: Contd.....

\begin{tabular}{|c|c|c|c|c|c|c|c|c|c|c|c|}
\hline $\begin{array}{l}\text { Source of } \\
\text { Variation }\end{array}$ & Years & d.f. & $\begin{array}{c}\text { Fruit } \\
\text { circumference } \\
(\mathrm{cm})\end{array}$ & $\begin{array}{c}\text { Number of } \\
\text { fruits per } \\
\text { plant }\end{array}$ & $\begin{array}{c}\text { Average } \\
\text { fruit weight } \\
\text { (kg) }\end{array}$ & $\begin{array}{c}\text { Fruit yield } \\
\text { per plant } \\
(\mathrm{kg})\end{array}$ & $\begin{array}{c}\text { T.S.S. } \\
(\%)\end{array}$ & $\begin{array}{c}\text { Ascorbic acid } \\
(\mathrm{mg} / \mathbf{1 0 0 g})\end{array}$ & $\begin{array}{l}\text { Reducing } \\
\text { sugar }(\%)\end{array}$ & $\begin{array}{c}\text { Non- } \\
\text { reducing } \\
\text { sugar }(\%) \\
\end{array}$ & $\begin{array}{c}\text { Dry } \\
\text { matter } \\
(\%)\end{array}$ \\
\hline \multirow{2}{*}{ Replications } & $\mathrm{Y}_{1}$ & 2 & $2.47 * *$ & 0.26 & 0.006 & 0.051 & $0.17 * *$ & 0.05 & 0.002 & 0.003 & 0.02 \\
\hline & $\mathrm{Y}_{2}$ & 2 & $1.67 *$ & 0.15 & 0.016 & $0.44 *$ & 0.02 & $0.07 *$ & 0.002 & 0.004 & 0.04 \\
\hline \multirow{2}{*}{ Genotypes } & $\mathrm{Y}_{1}$ & 35 & $1.72 * *$ & $1.64 * *$ & $0.020 * *$ & $2.28 * *$ & $0.51 * *$ & $2.19 * *$ & $0.11 * *$ & $0.025^{* *}$ & $0.50 * *$ \\
\hline & $\mathrm{Y}_{2}$ & 35 & $2.19 * *$ & $1.34 * *$ & $0.020 * *$ & $2.50 * *$ & $0.58 * *$ & $1.92 * *$ & $0.20 * *$ & $0.040 * *$ & $0.45 * *$ \\
\hline \multirow{2}{*}{ Error } & $\mathrm{Y}_{1}$ & 70 & 0.49 & 0.27 & 0.005 & 0.23 & 0.035 & 0.043 & 0.006 & 0.002 & 0.023 \\
\hline & $\mathrm{Y}_{2}$ & 70 & 0.51 & 0.15 & 0.005 & 0.14 & 0.029 & 0.019 & 0.02 & 0.003 & 0.016 \\
\hline
\end{tabular}

*, ** Significant at 5 per cent and 1 per cent probability levels, respectively 
Table 2: Estimates of mean, range, coefficient of variation, heritability and genetic advance in bottle gourd over two years $\left(\mathrm{Y}_{1}, \mathrm{Y}_{2}\right)$

\begin{tabular}{|c|c|c|c|c|c|c|c|c|}
\hline \multirow{3}{*}{ Characters } & \multirow{3}{*}{ Years } & \multirow{2}{*}{$\begin{array}{c}\text { Grand } \\
\text { mean }\end{array}$} & \multicolumn{2}{|c|}{ Range of mean values } & \multicolumn{2}{|c|}{ Coefficient of variation } & \multirow{2}{*}{$\begin{array}{c}\text { Heritability in } \\
\text { broad sense }(\%)\end{array}$} & \multirow{2}{*}{$\begin{array}{c}\text { Genetic advance in } \\
\text { per cent of mean }\end{array}$} \\
\hline & & & Parents & Crosses & PCV & GCV & & \\
\hline & & 1 & 2 & 3 & 4 & 5 & 6 & 7 \\
\hline \multirow{2}{*}{$\begin{array}{c}\text { Days to first staminate flower } \\
\text { opening }\end{array}$} & $\mathrm{Y}_{1}$ & 45.49 & 42.53 to 46.80 & 41.83 to53.49 & 5.46 & 4.49 & 69.00 & 7.67 \\
\hline & $\mathrm{Y}_{2}$ & 44.62 & 41.55 to 47.57 & 40.54 to 52.94 & 5.73 & 5.13 & 80.10 & 9.46 \\
\hline \multirow{2}{*}{$\begin{array}{c}\text { Days to first pistillate flower } \\
\text { opening }\end{array}$} & $\mathrm{Y}_{1}$ & 48.21 & 44.63 to 52.40 & 44.90 to55.93 & 5.39 & 4.60 & 72.70 & 8.07 \\
\hline & $\mathrm{Y}_{2}$ & 47.22 & 45.18 to50.60 & 41.19 to56.63 & 5.55 & 4.85 & 76.30 & 8.73 \\
\hline \multirow{2}{*}{$\begin{array}{l}\text { Node number to first } \\
\text { staminate flower }\end{array}$} & $\mathrm{Y}_{1}$ & 9.92 & 7.26 to 12.27 & 8.28 to 11.90 & 13.31 & 10.31 & 60.00 & 16.43 \\
\hline & $\mathrm{Y}_{2}$ & 9.42 & 7.19 to 11.15 & 7.89 to 12.57 & 14.38 & 11.56 & 64.60 & 19.11 \\
\hline \multirow{2}{*}{$\begin{array}{c}\text { Node number to first pistillate } \\
\text { flower }\end{array}$} & $\mathrm{Y}_{1}$ & 13.94 & 13.39 to 15.17 & 12.00 to 16.03 & 8.73 & 6.00 & 47.30 & 8.54 \\
\hline & $\mathrm{Y}_{2}$ & 13.60 & 11.07 to 16.48 & 11.37 to 16.10 & 11.43 & 8.90 & 60.60 & 14.26 \\
\hline \multirow{2}{*}{ Days to first fruit harvest } & $\mathrm{Y}_{1}$ & 60.25 & 57.83 to 64.53 & 56.67 to 63.07 & 4.46 & 3.38 & 57.30 & 5.26 \\
\hline & $\mathrm{Y}_{2}$ & 58.68 & 56.33 to 65.33 & 54.33 to 68.33 & 5.22 & 8.56 & 76.20 & 8.20 \\
\hline \multirow{2}{*}{ Vine length (m) } & $\mathrm{Y}_{1}$ & 6.27 & 5.12 to 7.70 & 4.17 to 7.69 & 13.35 & 12.06 & 81.70 & 22.49 \\
\hline & $\mathrm{Y}_{2}$ & 5.60 & 4.85 to 6.07 & 4.60 to 7.37 & 13.90 & 10.01 & 51.90 & 14.82 \\
\hline \multirow{2}{*}{$\begin{array}{c}\text { Number of primary branches } \\
\text { per plant }\end{array}$} & $\mathrm{Y}_{1}$ & 14.99 & 11.31 to 18.00 & 10.22 to 21.55 & 20.15 & 18.09 & 80.60 & 33.42 \\
\hline & $\mathrm{Y}_{2}$ & 16.05 & 11.50 to 19.00 & 11.17 to 21.50 & 19.07 & 17.01 & 79.50 & 31.28 \\
\hline \multirow{2}{*}{ Fruit length $(\mathrm{cm})$} & $\mathrm{Y}_{1}$ & 45.37 & 39.40 to 46.47 & 41.50 to 50.90 & 7.11 & 6.14 & 74.70 & 10.93 \\
\hline & $\mathrm{Y}_{2}$ & 46.30 & 40.33 to 45.44 & 40.94 to 52.33 & 7.43 & 6.83 & 84.60 & 12.94 \\
\hline
\end{tabular}

Table 2: Contd.....

\begin{tabular}{|c|c|c|c|c|c|c|c|c|}
\hline & & 1 & 2 & 3 & 4 & 5 & 6 & 7 \\
\hline \multirow{2}{*}{$\begin{array}{l}\text { Fruit circumference } \\
(\mathrm{cm})\end{array}$} & $\mathrm{Y}_{1}$ & 24.20 & 23.38 to 25.12 & 23.23 to 26.40 & 3.91 & 2.64 & 45.50 & 3.68 \\
\hline & $\mathrm{Y}_{2}$ & 24.38 & 23.10 to 25.95 & 23.52 to 26.03 & 4.24 & 3.07 & 52.50 & 4.59 \\
\hline \multirow{2}{*}{$\begin{array}{l}\text { Number of fruits per } \\
\text { plant }\end{array}$} & $\mathrm{Y}_{1}$ & 5.22 & 3.96 to 6.03 & 4.28 to 6.86 & 16.41 & 12.96 & 62.30 & 21.07 \\
\hline & $\mathrm{Y}_{2}$ & 5.25 & 3.96 to 5.85 & 4.42 to 6.39 & 14.09 & 12.04 & 73.00 & 21.14 \\
\hline \multirow{2}{*}{$\begin{array}{l}\text { Average fruit weight } \\
(\mathrm{kg})\end{array}$} & $\mathrm{Y}_{1}$ & 1.12 & 0.98 to 1.19 & 0.94 to 1.31 & 9.09 & 6.30 & 48.00 & 8.93 \\
\hline & $\mathrm{Y}_{2}$ & 1.15 & 0.89 to 1.20 & 1.03 to 1.29 & 8.82 & 6.10 & 47.80 & 8.69 \\
\hline \multirow{2}{*}{$\begin{array}{l}\text { Fruit yield per plant } \\
(\mathrm{kg})\end{array}$} & $\mathrm{Y}_{1}$ & 5.80 & 4.21 to 6.84 & 4.51 to 8.15 & 16.54 & 14.26 & 74.30 & 25.34 \\
\hline & $\mathrm{Y}_{2}$ & 6.02 & 4.36 to 6.93 & 4.89 to 7.68 & 15.96 & 14.74 & 85.30 & 28.07 \\
\hline \multirow{2}{*}{ T.S.S. (\%) } & $\mathrm{Y}_{1}$ & 3.74 & 3.10 to 4.20 & 3.03 to 5.07 & 11.85 & 10.72 & 81.80 & 20.05 \\
\hline & $\mathrm{Y}_{2}$ & 3.95 & 3.18 to 4.40 & 3.20 to 5.00 & 11.72 & 10.89 & 86.40 & 20.76 \\
\hline \multirow{2}{*}{$\begin{array}{l}\text { Ascorbic acid } \\
(\mathrm{mg} / 100 \mathrm{~g})\end{array}$} & $\mathrm{Y}_{1}$ & 7.99 & 6.90 to 9.40 & 6.40 to 9.40 & 10.90 & 10.58 & 94.30 & 21.15 \\
\hline & $\mathrm{Y}_{2}$ & 8.06 & 6.96 to 9.41 & 6.50 to 9.40 & 10.03 & 9.88 & 97.00 & 20.10 \\
\hline \multirow{2}{*}{ Reducing sugar $(\%)$} & $\mathrm{Y}_{1}$ & 1.78 & 1.49 to 2.20 & 1.41 to 2.20 & 11.66 & 10.76 & 85.20 & 20.22 \\
\hline & $\mathrm{Y}_{2}$ & 1.98 & 1.68 to 2.30 & 1.60 to 2.50 & 14.25 & 12.27 & 74.20 & 21.72 \\
\hline \multirow{2}{*}{$\begin{array}{c}\text { Non-reducing sugar } \\
(\%)\end{array}$} & $\mathrm{Y}_{1}$ & 0.81 & 0.59 to 0.80 & 0.68 to 1.00 & 12.36 & 10.92 & 78.10 & 19.75 \\
\hline & $\mathrm{Y}_{2}$ & 0.85 & 0.72 to 1.00 & 0.66 to 1.09 & 14.50 & 12.97 & 80.00 & 23.53 \\
\hline \multirow{2}{*}{ Dry matter $(\%)$} & $\mathrm{Y}_{1}$ & 3.72 & 3.25 to 4.50 & 3.00 to 4.60 & 11.52 & 10.75 & 87.10 & 20.69 \\
\hline & $\mathrm{Y}_{2}$ & 3.87 & 3.10 to 4.30 & 3.23 to 4.50 & 10.35 & 9.82 & 90.00 & 19.12 \\
\hline
\end{tabular}

\section{References}

1. Johnson HW, Robinson HF, Comstock RE. Estimates of genetic and environmental variability in soybean. Agron. J 1955;47:314-318.

2. Mather K, Jinks JL. Biometrical genetics: the study of continuous variation, $2^{\text {nd }}$ eds. Champan and hall London 1971.

3. Narayana R, Singh SP, Shrama DK, Rastogi KB. Genetic variability and selection parameters in bottle gourd. Indian J Hort 1996;45:53-58.

4. Panse VG, Sukhatme PV. Genetics and quantitative characters in relation to plant breeding. Indian $\mathrm{J}$ Genet 1957; 17:312-328.

5. Sahni GP, Singh RK, Saha BC. Genotypic and phenotypic variability in ridge gourd (Luffa acutangula Roxb.). Indian J Agri. Sci 1987;57(9):666-668.

6. Singh NP, Narayan P, Dubey AK, Srivastava JP. Studies on combining ability, heritability and genetic advance in bottle gourd [Lagenaria siceraria (Mol.) Standl.] In: Abstract Book of National Seminar on Cucurbits Sept. G.B. Pant University of Agriculture and Technology, Pantnagar 2005;101:22-23.
7. Varalakshmi B, Rao PV, Reddy YN. Genetic variability and heritability in ridge gourd (Luffa acutangula) Indian J Agric. Sci 1995;65:606-610.

8. Wani KP, Ahmad N, Hussain K. Gene action studies in bottle gourd [Lagenaria siceraria (Mol.) Standl.]. Indian J Agric, Sci 2008;78(3):258-260. 